\title{
SOME ASPECTS OF THE TRANSFORMATION EDUCATIONAL SERVICES INTO A DIGITAL ENVIRONMENT
}

\author{
Anna Olegovna Zvereva $^{1^{\star}}$ and Maria Yuryevna Belyakova ${ }^{2}$ \\ ${ }^{1} \mathrm{PhD}$ in Economics, Associate Professor, Department Sport and Tourism management, Institute of \\ finance and sustainable development, The Russian Presidential Academy of National Economy \\ and Public Administration, Russian Federation, sw_an@mail.ru \\ ${ }^{2} \mathrm{PhD}$ in Economics, Associate Professor, Head of the Department Sport and Tourism \\ management, Institute of finance and sustainable development, The Russian Presidential \\ Academy of National Economy and Public Administration Russian Federation, \\ mbeliakova@ranepa.ru \\ ${ }^{*}$ Corresponding Author
}

\begin{abstract}
This article analyzes important trends that are currently formed in the activities of educational institutions of the Russian Federation related to the provision of educational services, taking into account the widespread introduction of digital technologies. Interaction with students by combining real and virtual processes is one of the global world trends. Increasingly, in addition to traditional forms of educational activity, distance technologies and remote communication methods are used.

The progressive and planned introduction and use of digital means in the educational process was disrupted, since the pandemic phenomenon covered all spheres of human life and the entire territory of the planet. To maintain the activity and integrity of the educational process, higher education institutions were forced to change their activities in a short time and use electronic tools in the educational process. In the context of the spread of coronavirus, educational institutions urgently adapted the process aimed at the formation of a knowledge system, the transfer of information, skills and abilities that must be carried out in the provision of educational services and transferred it to the digital environment. The article discusses the main aspects that affected this type of activity. Systematization of positive facts and experience, generalization of the difficulties that had to be faced in the formation of educational content at this stage allows us to identify new opportunities and methods that can be used in the work of different educational institutions.

It is important to note that educational content, depending on the essential content of academic disciplines, is not static. This is especially true for those disciplines that study the economic and financial aspects of the activities of modern enterprises. Changes in the requirements of international legislation, the variation of the content of regulatory documents on the territory of the Russian Federation is carried out constantly, therefore even the already formed educational content must be constantly improved. In this case, the load on optimization of the content of the discipline for operational adjustments in connection with the changes made may significantly increase. However, it is obvious that without the use of digital and information technologies focused on use in the educational process, it is now impossible to fully and efficiently train specialists for all sectors of the economy.
\end{abstract}

Keywords: education, high school education, on-line, Digital transformation, Covid-19. 


\section{INTRODUCTION}

Many higher educational institutions of the Russian Federation and other countries were forced to use digital technologies in the shortest possible time due to the threat of the spread of coronavirus infection to organize a continuous educational process. The possibilities for such application are wide, but the integration of such digital tools into practical work involves many difficulties. If earlier various educational online tools were considered as an alternative or addition to traditional classroom studies, in the current period the distance format has become the only possible way to continue learning. The readiness of specific educational institutions for this method of communication is not uniform. In addition, the readiness of university teachers and the ability to quickly adapt educational content to the requirements of the online environment has an important impact not only on the quality, but also on the possibility of implementing the whole educational process. The online learning format includes many features that must be taken into account when preparing training materials and adapting them to the digital environment. Recent unique trends have had a significant impact on the educational environment, initiating the formation and continuous improvement of educational resources of universities in the virtual space.

\section{LITERATURE REVIEW}

The provision of educational services in the online environment is associated with several issues that are of interest to a large number of researchers. Changes in connection with the threat of the spread of coronavirus affect many aspects of educational activities, regardless of the direction of the chosen training (Wlodarczyk, J.R. et al., 2020). All participants in the educational process are involved in the transformation of educational services into a digital environment. Online learning presupposes the formation of a special approach in students, aimed at mastering both basic concepts and specific knowledge and skills based on the chosen educational topic (Garcia CE, Yao CW, 2019) Reflection of various aspects of the educational process can be seen in earlier works of the authors (McClintock et al., 2013). There are features of the organization of the educational process in the electronic environment when obtaining economic and business education, which inevitably arise when using digital technologies, since it is important to disclose the issues of the economic practice of enterprises, which are very diverse (Turishcheva, 2020). Digital technologies have greatly changed the approach to learning and the very models of education delivery as information and communication technologies have improved (Kumar P. et al, 2019).

The specifics of teaching students who have chosen an economic, management, financial or business specialization is an important factor, since changes in the business environment are constantly occurring, both at the local and global levels. Teachers of educational institutions who contact students and form individual academic disciplines are forced to systematically update teaching materials, since the quality of a graduate's training depends on their understanding of general trends in the environment (Avvakumova, 2020). Changes in legislative aspects affect all economic aspects of the enterprise: consumer behavior, the choice of approaches to taxation and pricing (Akhmadeev, 2019), the formation of the accounting policy of commercial organizations (Turishcheva, 2019), other aspects of financial relationships (Zaporozhtseva, L. et al, 2020 ). Since the listed problems are extremely important, prospective graduates should be aware of them. For an employer involved in economic life, the issues of preparing a graduate for practical work are very important. (Grossman, 2017). The preferences of employers differ, since questions arise as to how professionally a graduate who received an online education can solve various (Lehoux et al, 2019) practical problems and build a successful career (Schworm, S., 2017).

And, finally, in the context of the Covid-19 pandemic, higher education institutions were forced to switch to distance learning as soon as possible, which also entailed several significant changes that were adopted urgently (Krishnamurthy, S., 2020). Further development and formation of communication between educational participants in the online environment has great potential: firstly, a clear geographical location and physical presence of the student are not required. On the other hand, there is a need for a clear formalization of the requirements for monitoring student progress in the digital space and learning effectiveness. Such conclusions can be done based on systematization of research in this area. (Arbaugh et al, 2009).

\section{MATERIALS AND METHODS}

In this work, we used several methods that are widely used in scientific research. Based on the observation of recent trends, it was possible to systematize the main factors that influence the use of distance learning 
models. Analysis of information on the procedure for the implementation of the educational process and the transformation of services into a digital field in the context of the spread of the coronavirus infection Covid-19 made it possible to identify a number of difficulties associated with conducting educational activities in an online environment.

\section{RESULTS}

Higher education is an important social component for any state. Its availability and quality, training of graduates capable of solving problems at a high level serves as an important indicator of the life of the population of any state. Average spending on education in the Russian Federation is approximately $3.5 \%$ of GDP. Among the listed sustainable development goals published in the Main messages for the 2020 Voluntary National Review by the Russian Federation about Sustainable Development Goals in Russia (UN) are the provision of universal and equitable quality education and the promotion of lifelong learning opportunities for all. One of the primary tasks contributing to the achievement of the stated goal is to ensure equal opportunities for all groups of the population in terms of obtaining high-quality higher education, which will allow graduates to achieve successful professional implementation. This is possible if young people who have graduated from higher educational institutions develop competence skills and abilities that provide professional competitive advantages. The number of educational institutions on the territory of the Russian Federation is given (Table 1). ${ }^{1}$

Table 1. Educational organizations of higher education in the Russian Federation.

\begin{tabular}{|l|l|c|c|c|c|c|}
\hline & $2000 / 01$ & $2005 / 06$ & $2010 / 11$ & $2016 / 17$ & $2017 / 18$ & $2018 / 19$ \\
\hline $\begin{array}{l}\text { Educational organizations of } \\
\text { higher education }\end{array}$ & 965 & 1068 & 1115 & 818 & 766 & 741 \\
\hline
\end{tabular}

An important trend that is inherent in the current stage of development of the world space is the widespread use of digital technologies in education. International globalization, the use of Internet technologies and the digitalization of the economy generally serve to popularize and distribute educational services. The spread of higher education, its availability outside a particular state helps to create conditions for the development of the most talented students. The availability of education using distance technologies and online learning is also associated with a decrease in the cost of educational services. There is another aspect of this phenomenon - adaptation of both students and teachers to distance learning is required, preparation and the ability to use new educational technologies in the educational process are required.

These facts are global trends, and they are also true for the educational system of the Russian Federation. In other words, what is happening in the global educational environment is reflected in the territory of the Russian Federation. The Government considers global trends when developing strategic objectives in the field of education, including directions for the development of higher educational institutions, universities, et al. The formation of a digital educational environment that meets modern requirements also applies to such tasks. Achievement of these indicators can be realized both by increasing the number of e-courses or individual disciplines, and by introducing distance forms of training in general for different educational programs. At the same time, digital technologies are a popular tool to support highly effective teaching methods.

But this fact, of course, makes it necessary to have the appropriate equipment and technical means in educational institutions. It is necessary to update the material and technical base, provide students with access to personal computers, including those with access to the Internet. It is a critical element reflecting digitalization processes in higher education institutions. The infrastructural aspect, that is, the provision of educational institutions with the material and technical base of an appropriate technological level, is very important. In the universities of the Russian Federation, there are about 25 personal computers per 100 students, which can be used for educational purposes, which in general allows organizing the educational process. However, the problem is that modern students prefer to work remotely, and the existing fixed assets of universities are used, as a rule, to resolve operational issues. At the same time, the re-equipment of the material and technical base of universities requires students to have specific digital competencies.

\footnotetext{
${ }^{1}$ Data from the Ministry of Science and Higher Education of the Russian Federation.
} 


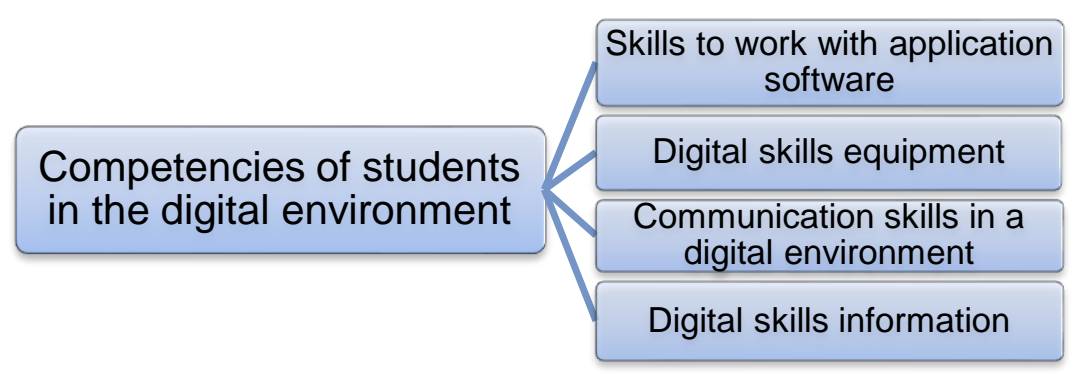

Fig. 1. Competencies of students in the digital environment

To ensure quality and affordable education in the context of digital trends, Russian educational institutions are actively using distance learning technologies, which may include open online courses on various platforms. Both Russian and foreign organizations can be the rightholders of the platforms. Until recently, such educational resources for the most part played the role of an advertising medium, which might not correspond to the ultimate goals of educational programs. At the same time, the quality of the content component of distance courses could vary significantly, often without revealing the essence and specifics of issues in terms of preparing graduates of the proper qualifications.

With the spread of coronavirus infection, distance education has become the most important way to maintain the continuity of the educational process. But conducting classes in the mode of remote computer communication with students, especially when teaching disciplines of economic, managerial and business profile, is rather difficult for several reasons. One of them is the asynchrony of the introduction of requirements for the order of presentation of academic disciplines that did not previously have electronic content in the digital environment. Concretization of the content of the curriculum of the educational discipline of the educational program within the framework of the chosen specialty is very closely related to the field of professional activity and the scope of further professional application. The types of tasks and objects of professional activity of students, the areas of knowledge of future graduates are multifaceted. (Kalacheva, 2019) and (Akhmadeev, 2019) On the one hand, we can talk about some of their differentiation. But to receive quality training for students as a result, they need to discuss highly specialized issues in the classroom together with the teacher. And the constant change in legislation makes the list of such issues very wide. Teachers are forced to endlessly research and analyze such changes (Morozova, 2020) and (Chaykovskaya, 2020).

Therefore, in the light of the above circumstances, it seems important to formalize the requirements for the implementation of educational programs during a pandemic. Efforts are required from a specific teacher to clearly delineate the areas of professional activity in a distance learning environment. Below are the possible approaches to providing the educational process online:

- The content of lectures in a distance environment should ensure the assimilation of the material in accordance with the topic of the lesson: such materials may contain both the teacher's own developments and text lecture materials and links to various external resources: (presentations, educational films, articles, documents, news material), other online resources;

- Materials are needed to control the assimilation of materials in the form of test items, taking into account the specifics of a particular lesson and designed to assess the degree of mastering by students;

- For organizing seminars, the teacher can form a list of questions for discussion at seminars, plans for practical lessons, materials for preparing for them in the form of notes and links to various external resources;

- Required test materials and other tasks tied to a specific lesson, which are designed to automatically assess the degree of its mastering by the student. This includes options for written work and guidelines for their implementation.

It is very important that both teachers and students adhere to the deadlines for communication: teaching materials should be posted in advance. You also need to control the timeliness of students' delivery of control, test, and other test tasks. In addition, the teacher must promptly respond to students' questions and promptly report the results of checking written works.

A number of tools can be used as a means of communication and ways of interaction between students and teachers: asynchronous written communication (interaction) in intra-university distance learning systems, 
which is most preferable. In practice, various messengers or various services for video conferences and online meetings are also applicable to promptly respond to students' questions.

\section{CONCLUSION}

As a result of this research, we can make some conclusions. The spread of the coronavirus infection Covid19 has affected all areas of activity in many countries. Educational institutions were forced to urgently introduce digital technologies into the educational process. To ensure the effectiveness of educational work, it became necessary in the shortest possible time to adapt training courses in various disciplines to distance learning conditions, to include them in the daily educational work of the university. The organization of a continuous educational process became possible thanks to the use of digital resources and services, ensuring the interaction of all participants in the educational process: students, representatives of the administration of educational institutions.

\section{REFERENCE LIST}

Wlodarczyk, J.R., Alicuben, E.T., Hawley, L., Sullivan, M., Ault, G.T., Inaba,K. (2020) Development and emergency implementation of an online surgical education curriculum for a General Surgery program during a global pandemic: The University of Southern California experience, The American Journal of Surgery, https://doi.org/10.1016/j.resuscitation.2020.04.041.

Garcia, C.E., Yao, C.W. The role of an online first-year seminar in higher education doctoral students' scholarly development, The Internet and Higher Education, Volume 42, 2019, p. 44-52, https://doi.org/10.1016/j.iheduc.2019.04.002.

MClintock, C., Benoit, J., Mageean, D.(2013) Online graduate education Council of Graduate Schools, Washington, D.C. (2013)

Turishcheva, T., Akhmadeev, R., Bykanova, O. and Nastasyuk, N. (2020) Methodological Support for Internal Control of Autonomous Institutions. International Journal of Applied Exercise Physiology. vol. 9 (4), p. 53-61

Kumar, P., Kumar, A., Palvia, S., Verma, S. (2019) Online business education research: Systematic analysis and a conceptual model, The International Journal of Management Education, Volume 17, Issue 1, 2019, P. 26-35, https://doi.org/10.1016/j.ijme.2018.11.002.

Avvakumova, I.V., Bykanova, O.A. and Akhmadeev, R.G. (2020) Improvement of small business owners taxation. In the Proceedings of the 7th International Conference on Education and Social Sciences (INTCESS), p. 532-537

Akhmadeev, R.G., Bykanova, O.A. and Salomadina, P.S. (2019). The effect of the VAT change on the final consumer. Proceedings of the 33rd International Business Information Management Association Conference, IBIMA 2019: Education Excellence and Innovation Management through Vision 2020, p. 765-770.

Turishcheva, T.B. and Shugurova, S.A. (2019) Actual Aspects of Formation of Accounting Policies for Taxation Purposes of Commercial Organizations. Proceedings of the 34th International Business Information Management Association Conference, IBIMA 2019: Education Excellence and Management of Innovations through Sustainable Economic Competitive Advantage Vision 2025, p.4893-4898

Zaporozhtseva, L., Malitskaya, V., Chirkova, M., Tkacheva, Y. and Kuznetsova, I.(2020). Financial mechanism for commercial organization development: vector approach. International Transaction Journal of Engineering, Management \& Applied Sciences Technologies, vol.11 (7).

Grossman, A., Johnson, L. How employers perceive online accounting education: Evidence from Kentucky, Journal of Accounting Education, Volume 40, 2017, Pages 19-31, https://doi.org/10.1016/j.jaccedu.2017.06.002.

Lehoux, L., Morozova, T.V., Safonova, E.G., Balashova, A.D. and Protasov, M.V. (2019) Practical Aspects in 
Calculating of Impairment of Financial Assets According to IFRS 9 "Financial Instruments". Proceedings of the 33rd International Business Information Management Association Conference, IBIMA 2019: Education Excellence and Innovation Management through Vision 2020, p. 6624-6632.

Schworm, S., Loic Cadin, Carbone, V., Festing, M., Leon, E, Muratbekova-Touron, M., The impact of international business education on career success-Evidence from Europe, European Management Journal, Volume 35, Issue 4, 2017, Pages 493-504, ISSN 0263-2373, https://doi.org/10.1016/j.emj.2017.02.009.

Krishnamurthy, S. (2020) The future of business education: A commentary in the shadow of the Covid-19 pandemic, Journal of Business Research, Volume 117, 2020, Pages 1-5, https://doi.org/10.1016/j.jbusres.2020.05.034.

Arbaugh, J.B., Godfrey M., Johnson,, M., Pollack, B.L., Niendorf B., Wresch, W. (2009) Research in online and blended learning in the business disciplines: Key findings and possible future directions, The Internet and Higher Education, Volume 12, Issue 2,2009,P 71-87, https://doi.org/10.1016/j.iheduc.2009.06.006.

Kalacheva, O. N. (2019) A Survey of Modern E.U. Approaches towards Amortization Policies. Proceedings of the 34th International Business Information Management Association Conference, IBIMA 2019: Education Excellence and Management of Innovations through Sustainable Economic Competitive Advantage Vision 2025, p. 4515 - 4522

Akhmadeev, R., Morozova, T., Voronkova, O. and Sitnov. A. (2019). Targets determination model for VAT risks mitigation at B2B marketplaces. Entrepreneurship and Sustainability Issues, vol. 7(2), p. 11971216.

Morozova, T., Akhmadeev, R., Lehoux, L., Yumashev, A., Meshkova, G. and Lukiyanova, M. (2020). Crypto asset assessment models in financial reporting content typologies, Entrepreneurship and Sustainability Issues, vol. 7(3), p. 2196-2212.

Chaykovskaya, L.A., Turishcheva, T. B. and Akhmadeev R. G. (2020). Functional application of the internal control system in autonomous institutions. Bulletin of the National Academy of Sciences of the Republic of Kazakhstan. vol. 1 (383), p. $163-171$.

Sustainable Development Goals in Russia . Voluntary National Review 2020. Main messages for the 2020 Voluntary National Review by the Russian Federation. [Electronic resource]. URL: https://sustainabledevelopment.un.org/index.php?page =view\&type $=30022 \& n r=1686 \&$ menu $=3170$ (date of access: 30.08 .20 )

Education in numbers. Statistical collection. [Electronic resource]. URL: https://www.hse.ru/data/2019/08/12/1483728373/oc2019.PDF. (date of access: 25.08.20) 